http://dx.doi.org/10.22351/nepp.v44i1.3168

\title{
Secaram o Oásis: gestões e in-digestões da res Batista no caso e ocaso do Seminário Teológico Batista do Sul do Brasil
}

\author{
The Oásis drought: managements and "not-managements" of the res Baptist in the case \\ and at the end of the Southern Baptist Theological Seminary of Brazil
}

Sérgio Ricardo Gonçalves Dusilek*

\begin{abstract}
Resumo
O texto propõe apresentar uma síntese histórica de como o Seminário do Sul, outrora a principal casa de saber teológico dos batistas brasileiros, perdeu seu brilho, seu encanto. Nesse sentido analisaremos parte da gestão que sucedeu à do Pr. David Malta do Nascimento, especialmente ao sintomático e simbólico caso da perda dos apartamentos. Ao fazer isso, relacionamos esse caso dentro da referida Instituição como exemplo para a falta do esperado crescimento batista, com consequente declínio de interesse na pauta das pesquisas sociais.
\end{abstract}

\section{Palavras-chave}

Batistas. Seminário do Sul. Ciência da Religião. Economia.

\begin{abstract}
The purpose of the present text is to bring an analitic synthesis on how the South Brazil Theological Seminary, which used to be the main theologic space of knowledge in Brazil, lost its glow and its charm. In this sense, we will be analyzing part of the administration that succeeded Dr. David Malta do Nascimento, mainly where it refers to the symptomatic and symbolic case about the loss of the apartment buildings on the seminary campus area. As we do it, we are relating this case occured inside the institution mentioned above, as an example for the lack of the expected Baptist growth, which leads to the decline of interest on the social researches agenda.
\end{abstract}

Keywords

Baptists. South Baptist Seminary. Religious Science. Economy.

[Texto recebido em novembro de 2017 e aceito em julho de 2018, com base na avaliação cega por pares realizada por pareceristas ad hoc]

* Mestre em Ciência da Religião (UFJF). Doutorando em Ciência da Religião (UFJF). Viveu 14 anos como filho de professor no Seminário do Sul e, após um interstício de 10 anos, frequentou a "Colina" por mais 4 anos como aluno de teologia. Pastor na Igreja Batista Marapendi, Rio de Janeiro/RJ. E-mail: sdusilek@gmail.com 


\section{Introdução}

Na década de oitenta, o falecido Prof. Darci Dusilek (1985) ${ }^{1}$ escreveu um visionário texto sobre a Denominação Batista no qual, entrelinhas, defendia a percepção de que o Seminário Teológico Batista do Sul do Brasil (STBSB) representava um verdadeiro Oásis, conquanto não o único, no mundo teológico batista brasileiro. Tal defesa se dava especialmente diante do desenfreado e crescente aumento na oferta de cursos, institutos e seminários teológicos no Brasil. A tese geral de Dusilek é que o Seminário do Sul deveria permanecer no seu caminho de excelência teológica, ao passo que as condições que viabilizaram o florescimento do STBSB como esse oásis deveriam ser mantidas para que produção teológica e piedade, pensamento e preparo ministerial prosseguissem tendo aquele espaço como solo fértil para sua consecução.

Ao que tudo indica o Oásis secou. O filete remanescente é a sua especial Biblioteca. A questão que se coloca é como isto pode acontecer ao Seminário do Sul. Daí a proposição deste artigo, de mostrar esse processo de aridez que foi tanto interno quanto da ambiência da Convenção Batista Brasileira (CBB). O que expomos aqui é que o STBSB foi atingido por três ondas, sendo uma delas a série crise administrativa vivida pela CBB, mais especificamente a partir da década de noventa.

O Seminário Teológico Batista do Sul do Brasil (STBSB) é uma instituição centenária que, até a década de noventa, era a principal casa de formação teológica dos batistas brasileiros. Em número de alunos podia ser considerado o maior entre os seminários do protestantismo histórico. Sua influência, na década de oitenta podia ser vista no intercâmbio com outras instituições como a Escola Superior de Teologia (EST) e o Instituto Superior de Teologia em São Bernardo do Campo (SP), especialmente nos congressos da Associação de Seminários Teológicos (ASTE) que reunia em seus quadros tais instituições. Outro sinalizador de sua influência estava no acolhimento de alunos de várias partes do Brasil e de países da América do Sul.

Fato é que o Seminário do Sul foi responsável pela formação de grande parte da liderança batista no Brasil ao longo do século XX, e como tal deve ser considerado. Além de pastores, diversos ex-alunos daquela instituição enveredaram pelos caminhos do ensino universitário.

Ao pontuar essa realidade destacamos a lacuna que há no trato da Ciência da Religião no Brasil no tocante ao seu objeto de estudo e o intrínseco relacionamento que nele há com as questões econômicas. Até mesmo pela existência de um grande número de excentricidades religiosas que ocupa parte da atenção dos pesquisadores, ou mesmo por outros enfoques de suma importância que precisam ser igualmente tratados (seja no campo da hermenêutica, da arte, da fenomenologia, da busca por um estatuto da religião), a pesquisa em torno de assuntos econômicos ligados à religião vem sendo preterida.

1 Darci Dusilek faleceu em agosto de 2007. 
Ainda mais quando o enfoque se volta para uma denominação histórica como é o caso dos Batistas que será analisado nesse artigo.

Com preterimento ou não, digno de nota é que Max Weber já apontava para esse relacionamento imbricado entre economia e religião. ${ }^{2}$ Há muito do espírito capitalista na ética protestante, ao mesmo tempo que essa postura ética individualista sedimentou o caminho para a expansão do capitalismo enquanto sistema. Economia e Religião se entrelaçam também em Voltaire. ${ }^{3}$ Em sua sexta carta filosófica, o filósofo francês usa de uma imagem capitalista - a Bolsa de Londres - para ironizar o espaço da tolerância religiosa, dizendo que ali na Bolsa diferentes credos conviviam com mais liberdade que aquela exalada nos espaços eminentemente religiosos. De modo irônico Voltaire fazia uma denúncia a uma prática religiosa vazia, numa alusão a uma religiosidade desprovida de alma, de coração, e que paradoxalmente podia ser encontrada na Bolsa de Valores.

Uma pesquisa relativamente recente do Prof. Dr. Leonildo S. Campos abordou a relação da economia com a religião ao tratar da Igreja Universal do Reino de Deus. ${ }^{4}$ Tratase de um exaustivo, denso e sugestivo trabalho. Contudo ao citá-lo destaca-se que pouca atenção tem sido dada à relação entre economia e religião nos grupos protestantes históricos. E justamente neles é que há uma quantidade crescente de material voltado para essa temática.

Parte deste preterimento reside numa espécie de perda da relevância social dos batistas, ainda que no último recenseamento do IBGE (realizado em 2010) ele tenha apontado um crescimento. Segundo a tabela 1.4.6 do referido Censo, os batistas são o $3^{\circ}$ principal agrupamento religioso evangélico no Brasil, com 3.723.853 habitantes, ficando atrás da Assembléia de Deus (12.314.410) e "Evangélicos não determinados" (9.218.129). ${ }^{5}$ Aquela que já foi na primeira metade do século XX a principal denominação evangélica no Brasil assistiu sua primazia ser passada para grupos pentecostais, especialmente a Assembleia de Deus. Algumas razões são conhecidas e recorrentes na pesquisa social para explicar esse fato, tais como: a) o fato da matriz pentecostal mais falar ao povo brasileiro; b) a ligação dos batistas ao protestantismo de missão, cuja influência e tradição americanas foram sentidas ao longo de todo o século XX; c) o apoio à ditadura militar de 1964 e o racha denominacional ocorrido no início da década de 1960 na Convenção Batista Brasileira (CBB), que se constituíram em insumos para o enrijecimento estrutural e litúrgico dos batistas.

2 WEBER, Max. A ética protestante e o espírito do capitalismo. São Paulo: Martin Claret, 2002.

3 VOLTAIRE. Cartas Inglesas ou Cartas Filosóficas. São Paulo: Abril, 1973. p. 7-63 (Coleção Os Pensadores, 1.ed.)

4 CAMPOS, Leonildo Silveira. Teatro, templo e mercado: organização e marketing de um empreendimento neopentecostal. Petrópolis: Vozes; São Paulo: Simpósio/UMESP, 1997.

5 CENSO DEMOGRÁFICO 2010. Características gerais da população, religião e pessoas com deficiência. Rio de Janeiro: IBGE, 2012. Disponível em: <https://biblioteca.ibge.gov.br/visualizacao/periodicos>. Acesso em: 16 nov. 2017. p. 149. 
No entanto, muito pouco se falou das inúmeras crises administrativas internas pelas quais as denominações protestantes históricas, dentre elas os batistas, passaram. Defendemos aqui que parte do não crescimento, ou mesmo da não continuidade do seu crescimento se deu pelas incansáveis lutas internas oriundas da disputa de poder e da má administração patrimonial. Os batistas passaram a administrar o passivo e o passado, ao invés de prospectar e sonhar com o futuro.

Como exemplo dessa situação, propomo-nos a analisar o caso do Seminário Teológico Batista do Sul do Brasil, oferecendo maior foco sobre a gestão do Pr. Ebenézer Soares Ferreira. Entende-se que ao longo do texto ficará claro o porquê desta opção. A título de ilustração da deficiência administrativa, abordaremos mais detidamente a rumorosa perda dos apartamentos, a qual será explicitada mais adiante. Ao procedermos essa análise tencionamos evidenciar que alguns fatores aqui presentes se repetiram em diferentes organizações batistas, bem como nas demais denominações históricas presentes no Brasil. E como não pode ser diferente, tais fatos repercutiram na organização social e no pensamento teológico destes grupos e, no caso aqui proposto, dos Batistas da CBB.

A pesquisa foi realizada em março de 2015 com a devida autorização do então Reitor Luis Alberto Teixeira Sayão. O trato do material coletado seguiu a perspectiva da Escola de Analles, pela qual o historiador social extrapola a dimensão de um mero cronista e procura traçar um enredo, ${ }^{6}$ fornecendo coerência e coesão na ligação dos fatos históricos que, embora separados seja pelo tempo ou mesmo pelo espaço, possuem uma ligação simbólica. Além desta, Hayden White, ao citar Paul Ricoeur, fala também de uma estrutura da temporalidade está presente tanto no discurso narrativo, quanto nas ações dos agentes históricos, ${ }^{7}$ configurando a experiência humana em termos simbólicos. Os próprios agentes históricos prefiguram suas vidas como história com enredos. ${ }^{8}$ Desse modo um historiador pode produzir uma ficção que reconta um período da história, mesmo porque a narrativa histórico-literária afirma que os eventos ali contidos aconteceram e sugere figurativamente uma ordem e significado maior. ${ }^{9}$ Nesse sentido é que Ricoeur vê força na identificação entre história e literatura (novela), ao mesmo tempo em que não abole a distinção entre ficção literária e historiografia. ${ }^{10} \mathrm{Na}$ verdade, a narrativa pode fundir ao mesmo tempo o simbólico e o realístico. ${ }^{11}$ Tal perspectiva foi perseguida ao longo deste texto.

6 DUSILEK, Sérgio Ricardo Gonçalves. O encontro da História com a religião na narratividade de Paul Ricoeur. Conferência apresentada no $1^{\circ}$ Simpósio Conhecer e Fazer História promovido pela UNISUAM, Rio de Janeiro, 31 ago. 2017.

7 WHITE, Hayden. The Metaphysics of Narrativity: Time and symbol in Ricoeur's philosophy of history. In: WOOD, David (Ed.). On Paul Ricoeur: narrative and interpretation. London and New York: Routledge, 1991. p. 142.

8 WHITE, 1991, p. 145.

9 WHITE, 1991, p. 149.

10 RICOEUR apud WHITE, 1991, p. 147.

11 WHITE, 1991, p. 149. 


\section{Uma Gestão Complicada}

Conhecido líder batista, radicado no norte fluminense onde exercia grande influência, Ebenézer Soares Ferreira (1926-) já tinha sido presidente da principal convenção batista estadual, a Fluminense, ${ }^{12}$ e também presidente da Convenção Batista Brasileira em 1969 e 1971. À época de sua eleição e chegada no Seminário do Sul como seu novo reitor, dirigia o Colégio Batista de Campos além de ser pastor da Igreja Batista de Guarus, na mesma cidade. Por essas razões, era tomado como bom administrador e doutrinariamente firme e seguro, o que encantava as linhas mais conservadoras da denominação.

Tais linhas por sinal estavam bem ativas nesse período. $O$ renascimento do fundamentalismo protestante no Sul dos Estados Unidos no meio dos batistas, com paulatina tomada do poder em todas as instâncias da Convenção Batista do Sul (South Baptist Convention) e destituição dos reitores e professores de seminários com mentes mais arejadas foi sentido por aqui. Interessante que no mesmo ano (1984) os reitores dos dois principais seminários da denominação batista, o Seminário Teológico Batista do Sul do Brasil (STBSB) sediado no Rio de Janeiro, e o Seminário Teológico Batista do Norte do Brasil (STBNB) baseado em Recife, entregaram seus cargos. Os Drs. David Malta do Nascimento e Davi Mein se anteciparam ao movimento que estava por ecoar aqui. Na ata da Junta Executiva da CBB ${ }^{13}$ de 13 de dezembro de 1983 está registrada a comunicação da decisão da entrega do cargo de reitor pelo Pr. David Malta Nascimento.

Olhando mais especificamente para o caso do Seminário do Sul, conquanto o Pr. David Malta elegantemente tenha, em seu memorial de despedida, negado a saída por qualquer tipo de pressão, ele deixa pistas do que já vinha acontecendo. Ao citar um exprofessor da casa, Pr. João Reinaldo Purim, de linha mais conservadora, Pr. David destaca um importante viés para a educação teológica: “a educação teológica, pois, não limita a liberdade religiosa e doutrinária de quem se prepara para o ministério, mas o orienta a que procure desenvolver a unidade da fé cristã entre os crentes, na base do seu conhecimento individual da verdade revelada em Jesus Cristo". ${ }^{14}$

Nesse mesmo texto, Pr. David aponta para o vento estranho que estava vindo do Norte, da América. Ele assim assevera:

12 A Convenção Batista Fluminense conta com mais de 1200 igrejas em seu rol cooperativo, as quais se espalham por todo o Estado do Rio de Janeiro, menos a capital que conta com uma convenção própria (Convenção Batista Carioca) com mais de 500 igrejas em seu rol.

13 À época, a Junta Executiva da CBB era o órgão máximo da administração Batista. Na década de oitenta passou a chamar-se de Conselho de Planejamento e Coordenação da Convenção Batista Brasileira (CPCCBB), cuja principal mudança para o modelo anterior foi a incorporação da diretoria da Assembleia Convencional como diretoria do Conselho.

14 PURIM apud NASCIMENTO, David Malta do. Relatório da Junta do Seminário Teológico Batista do Sul do Brasil. In: ASSEMBLEIA DA CONVENÇÃO BATISTA BRASILEIRA, 1985, Maceió. Anais da 66a Assembleia da Convenção Batista Brasileira. Rio de Janeiro: CBB, 1986. p. 272. 
Parece que estamos retrocedendo. Algo de estranho acontece em nossos arraiais. Dá-nos a impressão de que estamos indo à reboque do que se passa lá fora, pelo simples vezo de imitar. Entretanto, não julgamos correto, nem de boa prática, sermos arrastados para porfias que nos são estranhas, não nos dizem respeito, não são nossas. Assim, com a pretensão de sermos mais realistas do que o rei, lideramos para o obscurantismo e o retrocesso. Ouvi, alhures, que algumas pessoas estão preocupadas pelo acesso que os estudantes têm a livros teológicos de fontes diferentes. Espantei-me. Será que, nesta altura dos acontecimentos queremos imitar a Igreja Católica, com seus interditos proibitórios, que fizeram a história da inquisição, de triste memória? Não chego a acreditar. No mínimo, a informação não corresponde à verdade. Foi um equívoco...15

Ao fazer um balanço final de sua gestão, que de tão marcante mantém o Seminário do Sul funcionando até os dias atuais, mesmo após 30 anos de sua saída, Pr. David Malta dá o seu recado contra essa onda fundamentalista cujas escuras nuvens já podiam ser vistas. Numa brilhante e sintética exposição, mostra como o papel do Seminário vinha sendo efetivamente desempenhado, no porque dele ser um Oásis:

O Seminário Teológico Batista do Sul do Brasil, graças a Deus tem mantido o necessário equilíbrio e a indispensável moderação. Vem formando obreiros, doutrinariamente sólidos, para o ministério das Igrejas e o trabalho missionário, sem descurar a responsabilidade de oferecer condições para a reflexão teológica, que, de resto, deve contribuir para que sejamos fiéis intérpretes da revelação divina e instrumentos do seu amor. ${ }^{16}$

Infelizmente seus dizeres proféticos não foram ouvidos. Prova disso é que houve todo um movimento e envolvimento para trabalhar essa vacância, o que reforça a tese de que os Drs. Malta Nascimento e Mein leram corretamente o que estava para acontecer. Ao saírem por vontade própria, não precisaram passar pelo imerecido desgaste de uma destituição, tal qual ocorreu no sul estadunidense.

Esse envolvimento para preencher a vacância, no caso da reitoria do Seminário do Sul, está registrado em três principais movimentos. O primeiro dá conta da nomeação do próprio Ferreira como relator da comissão de indicações ${ }^{17}$ em 19 de janeiro de 1984 na Assembleia da CBB ocorrida em Porto Alegre.18 A nomeação feita pelo presidente Pr.

15 NASCIMENTO, 1985, p. 272.

16 NASCIMENTO, 1985, p. 272.

17 Cabe à Comissão de Indicações compor as demais comissões, inclusive a de renovação de juntas e entidades, a qual nos interessa aqui.

18 Porto Alegre é um dado interessante. Ela representou o maior revés do Seminário do Sul dentro de uma campanha de desgaste que começara em 1980, quando na Assembleia de Goiânia, sérias e infundadas acusações foram feitas por um aluno contra o próprio Seminário (uma excrescência possível no sistema congregacional batista). O detalhe desta história é que Porto Alegre era a capital de um dos estados com a menor presença batista no país, mas que teve o "mérito" de atingir fortemente o Seminário do Sul. Ora, isso só foi possível porque líderes batistas já atuavam no processo de "fritura" da gestão David Malta. O revés se deu naquela Assembleia Convencional, mas não ficou restrito a ela, mesmo porque o redator de 
Nílson do Amaral Fanini, ${ }^{19}$ um líder brasileiro reconhecido e carismático e com grande trânsito na Convenção Batista do Sul dos Estados Unidos, aponta para o rumo que especialmente seria dado à composição das juntas, que elegerem seus executivos, e seus reitores (no caso dos seminários). Ao que parece, o poder estava sendo dividido e distribuído entre os conservadores e fundamentalistas. O relatório foi aprovado com alterações na $2^{\mathrm{a}}$ sessão da CBB de Porto Alegre. ${ }^{20}$

Além disso, houve um movimento promovido pela diretoria da CBB com a realização de uma reunião para tratar da futura gestão do Seminário do Sul. ${ }^{21}$ Tal reunião aconteceu à revelia do ainda Reitor Pr. David Malta do Nascimento, bem como da Junta do STBSB. Ao ser interpelada oficialmente por carta, na qual a Junta do STBSB comunicava

O Jornal Batista (OJB), Pr. José dos Reis Pereira, o mesmo que tinha cerceado toda e qualquer manifestação contrária ao Golpe de 1964, publica um artigo no OJB de 19 de fevereiro de 1984 de uma irmã batista de Porto Alegre, que colocava sob questionamento o próprio Seminário do Sul com sua gestão. O agravante desta história reside em três pontos: a) a ausência do contraditório: ora, como era o texto de uma leitora, ele, se tivesse que ser publicado, deveria ter sido feito com o contraditório pela direção do Seminário do Sul; b) o Seminário havia acabado de completar seu Jubileu de Brilhante; c) a autora do texto tinha uma restrição prévia (ZAMBROTTI, Renato Cerqueira. Entrevista concedida por email a Sérgio Ricardo Gonçalves Dusilek em 23 de maio de 2016) com o Seminário do Sul uma vez que perdera seu prometido "futuro" marido para uma musicista que cursava o Seminário do Sul (seu primo e namorado, prometido a ela por "acordo familiar" acaba por desmanchar o relacionamento quando vai estudar Teologia no Seminário do Sul na década de 1960). Destaca-se que não há como inferir se ela foi usada premeditadamente, cooptada por esse grupo de líderes que se propunha a desgastar o Seminário, ou mesmo se a autora do texto, ao fazê-lo, tinha a pálida noção da dimensão que sua contribuição tomaria. Ele ocasionou um acalorado debate por carta entre o Pr. David Malta Nascimento (Reitor do Seminário do Sul) e o Pr. José dos Reis Pereira (Redator do OJB), no qual Pereira aponta vários componentes do corpo docente do Seminário do Sul que, segundo sua visão institucional, representavam uma ameaça àquela "Casa de Profetas". Tais professores mencionados na carta e mais alguns outros, foram posteriormente desligados do corpo docente do Seminário do Sul, na gestão de Ebenézer Soares Ferreira que, conforme nota de rodapé "21" confirmou que esta foi a missão que lhe foi dada.

19 A influência de Fanini tanto dentro como fora de denominação batista pode ser vista no recebimento de uma concessão de canal de televisão na década de 1980, conforme artigo: CASTRO, Alexandre de Carvalho; DUSILEK, Sérgio Ricardo Gonçalves; SILVA, Clemir Fernandes. Identidade Social, Mídia Televisiva e Construção Histórico-Cultural da Memória Coletiva: o caso de um movimento sócioreligioso no Brasil. Religião e Sociedade, Rio de Janeiro, v. 36, n. 1, p. 74-102, 2016.

20 CONVENÇÃO BATISTA BRASILEIRA (1984). Ata da 65a Assembleia da Convenção Batista Brasileira. In: CBB. Livro do Mensageiro. Rio de Janeiro: CBB, 1985. p. 90.

21 Em entrevista concedida a este autor, Ferreira confirmou que além dos nomes citados, participaram do movimento de articulação para eleição do novo reitor do Seminário do Sul, entre outros, os Prs. José Reis Pereira, Nilson do Amaral Fanini, Samuel Cardoso Machado, João Falcão Sobrinho e Irland Pereira de Azevedo (FERREIRA, Ebenézer Soares. Entrevista concedida por email a Sérgio Ricardo Gonçalves Dusilek em 17 de junho de 2016 (b)), não sem antes se recusar, num primeiro momento, a decliná-los. Prosseguindo a entrevista, realizada por email, Ferreira asseverou que "realmente, solicitaram-me que professores que adotavam e pregavam o liberalismo fossem impedidos de dar aulas e desligados do corpo docente do Seminário do Sul" [sic] (FERREIRA, 2016a). Para este autor, a questão ali foi travestida de liberalismo teológico, o que não condizia com a realidade mesmo porque os acusados de tais práticas eram também pastores de algumas das principais Igrejas Batistas da Convenção Carioca. A questão era o ideário político, fato este indicado pela presença da tríade Fanini-Irland-Reis Pereira que apoiou o Golpe Militar e que agora articulava uma reformulação do corpo docente. Interessante é ver como o STBSB fomenta grupos exteriores e extratores. Já no início dos anos 2000, a composição de sua junta administrativa tinha cerca de $1 / 3$ de reitores de seminários de convenções batistas estaduais, o que denunciava à época, no mínimo um conflito de interesses. 
sua estranheza pela realização da referida reunião da sede da Junta Executiva da CBB22 para tratar de assuntos ligados ao Seminário do Sul, o secretário geral à época, Pr. João Falcão Sobrinho assim se explicou:

1. A reunião foi convocada pelo presidente da CBB [à época $\mathrm{Pr}$. Nilson do Amaral Fanini] "em pleno uso de suas prerrogativas";

2. A sede da Junta Executiva é sede da CBB;

3. Não cabe ao Secretário Geral da Junta impedir a ação do presidente;

4. O secretário foi também convocado e julgou que devia comparecer ao encontro;

5. O secretário só tomou conhecimento do assunto na reunião;

6. O secretário reconheceu a "prudência" do presidente;

7. O secretário não julga ter havido qualquer quebra de princípios que governam a cooperação denominacional. ${ }^{23}$

O terceiro movimento foi a pulverização de candidatos. Por ocasião da eleição do novo Reitor cinco nomes foram apresentados. Dentre eles, segundo a ata de eleição da Junta do Seminário do Sul, além de Ferreira, havia dois integrantes da Junta, os Prs. Artur Alberto da Motta Gonçalves e o presidente na ocasião, Josias Cardoso Machado. Foram indicados também o Pr. Orivaldo Pimentel Lopes, que acabou posteriormente ocupando o cargo de Secretário Geral da CBB e o professor Darci Dusilek, nome este aquiescido por parte do corpo docente e discente. Ao que nos parece, a pulverização de candidatos foi uma estratégia usada para o favorecimento da eleição de Ferreira.

Ora, esses expedientes escondem e revelam ao mesmo tempo o prenúncio de uma dificuldade de gestão. E com Ebenézer Ferreira ${ }^{24}$ não foi diferente. Conquanto assuma que seu início como reitor do Seminário do Sul tenha sido um período de "provações e de lutas", 25 ele não menciona que ele próprio foi o causador das tensões iniciais, ao iniciar o processo de desmantelamento do corpo docente que havia ali. ${ }^{26}$

22 Até 1985 a Junta Executiva da CBB era a esfera maior de poder da denominação batista, passando a adotar o nome de Conselho de Planejamento e Coordenação da CBB naquele mesmo ano, tendo como principais alterações: 1) a prerrogativa de ser a Convenção no interregno de suas Assembleias; 2) o fato da Diretoria eleita nas Assembleias da CBB ser a Diretoria também do CPCCBB.

23 CONVENÇÃO BATISTA BRASILEIRA (1984). Ata da reunião plenária da Junta Executiva da Convenção Batista Brasileira realizada em 28 de fevereiro de 1984. p. 54.

24 A título de esclarecimento, citamos o desejo do Pr. Ebenézer Soares Ferreira de que um historiador no futuro pontuasse sua gestão, fazendo uma "análise crítica desse período" (FERREIRA, Ebenézer Soares; HALLOCK, Edgar Francis. História do Seminário Teológico Batista do Sul do Brasil, 1908 a 1998. Rio de Janeiro: Dos Autores, 1998. p. 91).

25 FERREIRA; HALLOCK, 1998, p. 91.

26 Há uma "mancha" nesse período. E ela deve ser compreendida de modo literal. Ao tomar posse e logo após promover a demissão de alguns professores, parte do corpo discente reagiu pichando as salas de aula, com dizeres: "Fora reitor!" e "Abajo la dictadura!"[sic]. Esse último dizer denunciava a internacionalização do Seminário do Sul e a origem sul-americana do autor. 
Aqui cabe uma explicação. O Seminário do Sul no final dos anos 70 e início dos anos 80 tinha um qualificado corpo docente. Alguns doutores eram missionários americanos, muitos de linha mais moderada. Outra boa parte dos docentes era de brasileiros, entre mestres e doutores. Seus professores, além de uma bagagem ministerial, pois eram também em boa parte pastores, eram professores de inúmeros cursos nas mais diferentes Universidades do Grande Rio. Era comum ao aluno do Seminário do Sul se deparar com um de seus professores nos cursos de graduação e pós-graduação das Universidades e Faculdades que existiam no Grande Rio da época.

Havia também uma crescente aproximação com a Teologia da Libertação, especialmente com os escritos de Leonardo Boff. É difícil distinguir se o grupo de líderes batistas que arquitetou a tomada do poder no Seminário Batista do Sul o fazia motivado por um combate ao "liberalismo teológico" ou se o fazia com a intenção primeira de reprimir um pensamento político-social como era vista a Teologia da Libertação. Cabe ressaltar que o Brasil à época vivia o final do período da Ditadura Militar, justamente o período em que a liderança da CBB patenteou seu apoio aos militares. ${ }^{27}$ Fato é que se está diante de mais um clássico exemplo em que fundamentalismo e conservadorismo político se misturam.

Justamente a alma do Seminário do Sul, seu diferencial que era o corpo docente extremamente qualificado, foi desmantelada pela nova gestão. Contudo reparo seja feito: a perda não começou com sua posse, mas com sua eleição. Ao ser anunciada sua vitória o Seminário perdeu seu grande gestor acadêmico. Junto dele um dos professores saiu para dirigir o Instituto Bíblico de Ijuí/RS. No final do ano seguinte, 1985, após demitir três professores na sua chegada e instalar um ambiente de crise no Seminário, a casa perdeu mais dois dos seus maiores docentes. E em 1987 Ebenézer Ferreira leva a Junta do Seminário do Sul a demitir o Professor Israel Belo de Azevedo 28 e ainda naquele ano a exonerar o Professor Dr. José Roberto Pereira de Brito.

A primeira onda foi o desfazimento do corpo docente. O Seminário do Sul perdeu um corpo docente que conciliava qualidade acadêmica com bagagem ministerial e pastoral. A bagagem ministerial satisfazia em certo sentido parte das expectativas denominacionais, enquanto a formação acadêmica provia o curso com a devida qualidade no preparo teológico.

Parte da explicação para essa ruína docente do Seminário do Sul pode ser vista na marcação que Ferreira fez sobre sua gestão. Ele assinala como marcas do progresso na área

27 DUSILEK, Sérgio Ricardo Gonçalves; SILVA, Clemir Fernandes; CASTRO, Alexandre de Carvalho. A Igreja de Farda: Batistas e a Ditadura Civil-Militar. Estudos Teológicos, São Leopoldo, v. 57, n. 1, p. 192-212. jan./jun. 2017.

28 SEMINÁRIO TEOLÓGICO BATISTA DO SUL DO BRASIL (1987). Ata da reunião plenária da Junta Administrativa do Seminário do Sul no dia 20 de janeiro de 1987. Arquivos do Seminário Teológico Batista do Sul do Brasil. 
acadêmica as "ações meio": "a compra de equipamentos, o aumento da média para aprovação e o acompanhamento do estágio pelo capelão" ${ }^{29}$

Ao não perceber ou mesmo desconsiderar o que é realmente importante para uma instituição de ensino, Ferreira direcionou sua gestão para questões menores, apequenando-a. Ao invés de gerir a instituição, o Reitor se ateve preferencialmente a uma função de inspetoria de alunos. Numa das muitas vezes em que os alunos internos cometeram excesso em suas brincadeiras durante seu mandato, Ferreira convocou uma perícia para esclarecer e responsabilizar os culpados, ${ }^{30}$ dando ciência de problemas menores a toda a liderança denominacional. Ao fazê-lo, esqueceu-se que tal postura depunha contra o Seminário do Sul e contra sua própria imagem como gestor.

Ao trazer à baila esses apontamentos a gestão de Ferreira ganha tons reais. Fato é que após 14 anos como reitor entregou o seminário com somente quatro alunos a mais do que o último ano da reitoria do Pr. David Malta Nascimento, ocorrido em 1984, não obstante em seu relatório para o CPC da CBB de março de 1999 o Pr. Ebenézer Ferreira falar em "crescimento constante da matrícula". ${ }^{31}$ A nós parece que estes fatos corroboram para o fato de que o Pr. David foi responsável pela maior e mais visionária gestão que o STBSB já teve, atingindo seu ápice ainda em 1984. Nesse sentido, deve ser reconhecida a ação, ainda que extemporânea ao nosso ver, do Pr. Ebenézer Soares Ferreira ${ }^{32}$ no sentido de homenagear dois ex-reitores da casa, sendo um deles o Pr. David Malta do Nascimento.

Contudo a crise não ficou restrita à dimensão acadêmica do STBSB. Ela também perpassou a esfera administrativa. Além da diminuição dos recursos oriundos da $C B B, o$ STBSB teve sua credibilidade arranhada pelo caso da perda dos apartamentos. E esta foi a segunda onda. Onda que sobreveio num contexto de grande desgaste e desconfiança com a gestão batista. Após ver sua editora num estado pré-falimentar, os convencionais batistas passaram a se ater aos dados financeiros, rejeitando as demais informações. As gestões passaram a ser avaliadas como boas em decorrência do seu superávit financeiro. Ao perder parte do patrimônio, o STBSB perdeu também sua credibilidade institucional.

29 FERREIRA; HALLOCK, 1998, p. 92.

30 FERREIRA, Ebenézer Soares (1998). Relatório/novembro/1998. Arquivos do Conselho de Planejamento e Coordenação da CBB. p. 26.

31 FERREIRA, Ebenézer Soares (1999). Relatório/março/1999. Arquivos do Conselho de Planejamento e Coordenação da CBB. Outro fator que desdiz essa notícia é que no relatório de Março de 2000, sob a gestão interina do Pr. Vanderlei Marins, a Junta do Seminário do Sul relata a venda de uma casa na Rua Homem de Melo que lhe rendeu necessários R\$300.000,00 à época (CONVENÇÃO BATISTA BRASILEIRA (1999), Relatório/março/1999. Arquivos do Conselho de Planejamento e Coordenação da CBB). Ora, se houvesse essa expansão da qual se refere Ferreira, não seria necessária a venda de patrimônio.

32 Um destaque merece ser feito. O Pr. Ebenézer Soares Ferreira em seu último ano como reitor do STBSB, conduz à Junta a votar e reconhecer os Prs. João Filson Soren e David Malta Nascimento como reitores eméritos do Seminário do Sul (SEMINÁRIO TEOLÓGICO BATISTA DO SUL DO BRASIL (1998b). Ata da reunião plenária da Junta Administrativa do Seminário do Sul no dia 17 de março de 1998. Arquivos do Seminário Teológico Batista do Sul do Brasil). 


\section{O caso dos apartamentos como ponto de inflexão}

Novamente o visionário Pr. David Malta Nascimento marca sua passagem na história do Seminário do Sul ao provocar a Assembleia da Convenção Batista Brasileira reunida em Curitiba-PR em 1977, trazendo em seu relatório um pedido de autorização para permutar uma área de $2.550 \mathrm{~m}^{2}$ na Rua Homem de Melo por 18 apartamentos de três quartos. Como tal, a matéria foi apreciada pelo plenário daquela Convenção e aprovada três recomendações:

1. Que a Junta Administrativa do Seminário intensifique gestões no que diz respeito ao investimento imobiliário, devidamente assessorada por comissão técnica competente.

2. Que a Junta Administrativa fique autorizada a celebrar o respectivo contrato de permuta com a empresa que melhor condições oferecer, desde que asseguradas todas as garantias o êxito da transação.

3. Que esta Assembleia autorize a Associação Evangélica Denominada Batista no Rio de Janeiro a processar o desmembramento do terreno, e assinar as competente Escrituras para a efetivação de permuta. [sic] ${ }^{33}$

Não se sabe exatamente o porquê do Pr. David não ter dado prosseguimento à iniciativa visionária que teve. Fato é que esse assunto só foi retomado pela gestão seguinte no ano de 1987.

Numa forma tardia de prosseguimento às resoluções da Assembleia, a Junta do Seminário do Sul em 01 de abril de 1987 solicitou propostas a mais de 10 grandes empresas do ramo da Construção Civil, sendo que das cinco que responderam, optou-se pela Cláudio Macário Construtora Ltda, cuja razão social passou depois para Clama Construtora Ltda. ${ }^{34}$ Já em 15 de setembro de 1987, com o Pr. Ebenézer Soares Ferreira na reitoria, a Junta do STBSB pede à ASSOCIAÇÃO DENOMINADA EVANGÉLICA BATISTA DO RIO DE JANEIRO (ADEBRJ) ${ }^{35}$ a procuração para que promova o desmembramento da referida área, recebendo como resposta o pedido que a Convenção Batista Brasileira reiterasse a autorização concedida dez anos antes. Isso foi atendido em Janeiro de 1988 na 69ª Assembleia da Convenção Batista Brasileira realizada em Brasília, cuja decisão pela proposta do Pr. José Carlos Torres, foi para que o assunto ficasse sobre a

33 CONVENÇÃO BATISTA BRASILEIRA (1978). Anais da 59a Assembleia da CBB, 1978. In: CBB. Livro do mensageiro. Rio de Janeiro: CBB, 1979. p. 217.

34 Uma pequena nota é preciso ser feita aqui. O empresário Cláudio Macário era membro da PIB de Niterói, pastoreada pelo Pr. Nilson do Amaral Fanini.

35 Essa Associação foi criada no final do século XIX pelos missionários americanos com a finalidade de obter e manter o registro dos imóveis comprados à época. Isto porque com a ausência da laicidade no Brasil Império, não era permitido o registro de imóveis em nome de Igrejas oriundas do Protestantismo. Os terrenos comprados e registrados permanecem (os que não foram vendidos ou transferidos) até hoje em nome da ADEBRJ, com imunidade tributária. 
mesa, aguardando maiores "dados técnicos para a apreciação do plenário". ${ }^{36}$ As providências foram tomadas, especialmente no tocante à preocupação da $\mathrm{CBB}$ com a possível perda da imunidade tributária.

Por algum outro desconhecido (até esse momento) motivo, esse projeto permaneceu sem uma continuidade até que uma aspiração do coração da liderança batista ressurgisse. Falamos aqui do dourado sonho de uma espécie de cidadela batista, ${ }^{37}$ no qual todas as organizações e Juntas poderiam se abrigar num único endereço. Essa foi a terceira onda, a saber, a regionalização do Seminário do Sul. E a propriedade da colina era o encaixe perfeito para esse fim, apesar de se ter, vez por outra, inserções de convenções estaduais, como foi o caso da do Distrito Federal que convidou a Junta Patrimonial a construir sua sede num terreno doado, a qual remeteu à Convenção Batista Brasileira (CBB) o apelo para se ter um local que pudesse abrigar todas as Juntas da CBB. O encaminhamento desse assunto em Assembleia foi para que a ADEBRJ estudasse a possibilidade de abrigar todas estas entidades no terreno ocupado pelo Seminário do Sul. ${ }^{38}$

Diante destes novos fatos a Junta Administrativa do Seminário do Sul Teológico Batista do Sul do Brasil (STBSB) tomou a decisão de oferecer a propriedade da Rua Homem de Melo para construção da sede da CBB. ${ }^{39}$ A esse fato se sucedem duas oficiais correspondências do STBSB. A primeira, de 04 de dezembro de 1991, assinada pelo Reitor e enviada para a ADEBRJ oferece a área para o Conselho de Planejamento e Coordenação da Convenção Batista Brasileira (CPCCBB). Em 18 de dezembro de 1991, segue a segunda carta, com mesmo padrão e teor da primeira, só que destinada ao próprio Conselho de Planejamento e Coordenação da Convenção Batista Brasileira (CPCCBB).

A questão é que o Conselho da CBB conquanto não estivesse deficitário, não tinha condições naquele tempo de assumir esse empreendimento. Entendemos que possivelmente foi esse o fator que remeteu a Junta do Seminário do Sul à ideia primeira, original e visionária do Pr. David Malta do Nascimento. Só que de uma fonte permanente de receitas para o Seminário do Sul, a permuta do terreno da Rua Homem de Melo acabou se tornando numa fonte de despesas e descrédito.

\section{As Raízes da Perda dos Apartamentos}

36 CONVENÇÃO BATISTA BRASILEIRA (1988). Anais da 70a Assembleia da convenção batista brasileira, 1988. In: CBB. Livro do Mensageiro. Rio de Janeiro: CBB, 1989. p. 353.

37 Esse projeto hoje é uma realidade. Os prédios antes ocupados por alunos vindos de todo o Brasil, hoje estão tomados pela administração batista. Com isso, o Seminário do Sul que era de abrangência nacional, se tornou um seminário local, metropolitano. Uma sugestão de pesquisa que aqui fazemos é no sentido de demonstrar como isso aconteceu, quem foram seus principais agentes e que consequências trouxe ao STBSB. Além disso, seria bom notar se algum desses agentes teve sua formação teológica no Seminário do Sul.

38 CONVENÇÃO BATISTA BRASILEIRA, 1988, p. 291.

39 SEMINÁRIO TEOLÓGICO BATISTA DO SUL DO BRASIL (1991). Ata da reunião plenária da Junta Administrativa do Seminário do Sul no dia 12 de março de 1991. p. 4-5. 
A ideia de se ter uma nova fonte de receitas acabou não prosperando. Uma fonte de receita que o Seminário do Sul jamais criaria, pois não teria recursos para mexer na área onde seriam construídos os prédios acabou se tornando em elemento de descrédito. $\mathrm{O}$ próprio sucessor do Pr. David Malta, conquanto não fosse o idealizador do projeto, praticamente assume a paternidade da ideia reforçando em seu livro por duas vezes que tal empreendimento se tratava de uma "questão de visão". 40 Seja com aluguéis, como moradia funcional ou até com uma futura venda, tais imóveis dariam um novo fôlego financeiro ao Seminário do Sul.

O projeto à época era trocar um terreno rochoso e irregular por treze apartamentos nos dois blocos que ali seriam construídos. Os prédios receberiam nomes de dois líderes batistas já falecidos naquela ocasião. Contudo, somente uma unidade conseguiu ser vendida e o valor depositado na conta do Seminário. O resto foi perdido. Uma perda tão vultosa e flagrante como esta que ocorreu com o Seminário do Sul não advém de um único fator. Na verdade, vários, diferentes e estranhos fatores contribuíram para a construção não de um empreendimento, mas de um vexame administrativo.

O primeiro deles está associado com uma série de escrituras. Ao entrar no circuito a Construtora Brunet ${ }^{41}$ celebra junto com o Seminário do Sul (entidade que tinha a procuração da Associação Evangélica Denominada Batista do Rio de Janeiro - AEDBRJ) três escrituras diferentes. A primeira escritura, de promessa de compra e venda, foi celebrada em 23 de fevereiro de 1995, no $23^{\circ}$ Ofício do Rio de Janeiro-RJ, ${ }^{42}$ foi assinada pelo Reitor e por um membro da Junta, à época no campo fluminense, devidamente autorizados pela Junta do Seminário do Sul. Os procuradores, a saber, os pastores citados, nada mais fizeram do que cumprir uma decisão da Junta do Seminário do Sul. Nessa escritura, normal para esse tipo de empreendimento, continha cláusulas como a de número 22 que estabelecia a multa de $\mathrm{R} \$$ 800,00 por mês de atraso, por apartamento; e também a 26, que falava da hipótese de uma hipoteca bancária, a qual teria que envolver toda a Incorporação, mas que seria resguardado ao Seminário sua garantia pelo oferecimento de “a) hipoteca em igual valor; b) fiança bancária de empresa idônea; c) seguro de risco de crédito". É importante fixar essas condicionantes da cláusula 26, uma vez que após efetuada a Escritura de promessa de compra e venda, não há qualquer remissão a essas garantias.

A segunda e terceira escrituras foram celebradas no mesmo dia. Não antes de ter garantido o desmembramento do terreno onde seria feita a Incorporação. Em 18 de julho

40 FERREIRA; HALLOCK, 1998, p. 104.

41 A primeira construtora tinha sido a Wrobel Hilf Ltda, numa escritura de promessa de compra e venda assinada pelo então Reitor e um membro nomeado pela Junta do Seminário do Sul.

42 CARTÓRIO DO 23ํOㄷ́ㄷㅇ DO RIO DE JANEIRO, 1995; Ato 17, Livro 6250, Folha 155. 
de 1996 há uma correspondência do Reitor do Seminário ${ }^{43}$ para o presidente da ADEBRJ a fim de providenciar os documentos para que um funcionário da Construtora Brunet pudesse acompanhar o desmembramento e as demais medidas relacionadas ao terreno da Rua Homem de Melo, onde seriam construídos os prédios. Desmembramento feito, os equívocos se multiplicaram.

A segunda escritura, de compra e venda, foi feita em outra comarca, a cidade de Petrópolis. Ela foi celebrada no $11^{\circ}$ Ofício da Comarca de Petrópolis, ${ }^{44}$ no dia 27 de junho de 1997. Por ela a Construtora Brunet passou a ser detentora do imóvel, documento este que ela posteriormente iria apresentar ao Banco Itaú S/A para obter um financiamento, dando como garantia as unidades a serem construídas nos dois blocos de prédio, incluindo as que pertenceriam ao Seminário.

Já a terceira escritura foi feita no mesmo cartório que lavrou a "promessa de compra e venda". Trata-se de uma Escritura de Confissão de Dívida com Garantia Hipotecária, registrada no $23^{\circ}$ Ofício do Rio de Janeiro, RJ, em 27 de junho de $1997 .{ }^{45}$ Nela se estabelece o valor de $\mathrm{R} \$ 1.500 .000,00$ pela propriedade e se dá como garantia 7 unidades de 4 quartos (401-404; 501-503) e 6 unidades de 3 quartos (401-404; 503 e 504). Ela foi assinada pelos mesmos procuradores da primeira escritura e continha, entre outras: a) a cláusula 11 que previa imediata execução do contrato no caso de "inadimplemento de qualquer das obrigações estipuladas na escritura"; b) a cláusula 12.2 que dizia que a garantia que a Construtora Brunet dava era o imóvel/terreno onde seriam edificados os prédios, ou seja, ela dava como garantia para que o Seminário não perdesse a propriedade que ele declarara na $2^{a}$ escritura de compra e venda que havia "perdido", ainda que sob o nome da venda. Nessa mesma cláusula 12.2 havia a menção a essa escritura de compra e venda lavrada no $11^{\circ}$ Ofício da Comarca de Petrópolis, RJ; c) a cláusula 14 estabelecia que além das despesas ligadas a esse trâmite imobiliário (transferência, despesas cartorárias), a parte devedora seria responsável pelo registro da hipoteca no Cartório de Registro Imobiliário, tendo o prazo de 30 dias para sua execução. Por mais estranho que possa parecer, o Seminário do Sul outorgou ao devedor o registro da hipoteca. As cláusulas subsequentes como a 15 e 16 abordam as penalidades em caso de descumprimento da cláusula 14, as quais jamais saíram do papel. Alguns anos depois um presidente da Junta do Seminário do Sul declarou à diretoria da CBB “que a Escritura de Confissão de Dívida, que foi feita paralelamente à Escritura de Compra e Venda não foi registrada no prazo devido (30 dias) uma vez que foi confiado à construtora fazê-lo" (grifo nosso). ${ }^{46}$

43 Conquanto não tenha tido qualquer consecução, há o registro de um requerimento para informaç̃es sobre a situação financeira da Brunet (SEMINÁRIO TEOLÓGICO BATISTA DO SUL DO BRASIL (1996). Ata da reunião plenária da Junta Administrativa do Seminário do Sul no dia 27 de novembro de 1996. p. 53).

44 CARTÓRIO MURILO ASFORA, 1997; Ato 95, Livro 236, Folha 156.

45 CARTÓRIO DO $23^{\circ}$ OFÍCIO DO RIO DE JANEIRO, 1997, Ato 42, Livro 6924, Folha 085.

46 CONVENÇÃO BATISTA BRASILEIRA (2003). Ata da reunião da diretoria da Convenção Batista Brasileira realizada em 29 de novembro de 2003. 
No caso desta terceira escritura há outro fator que precisa ser destacado. $O$ Seminário do Sul aceitou como garantia da confissão de dívida, o terreno que era dele. É isso que está exalado na cláusula 12.2 acima descrita. Acima de quaisquer interpretações, de possíveis explicações para que uma entidade longeva como o Seminário do Sul aceitasse essa situação está o fato em si. E é sobre ele que jogamos luz com esse destaque. Até mesmo porque àquele que tem a missão de escrever compete o poder de iluminar certas partes em um texto. ${ }^{4}$

A Junta Administrativa do Seminário Teológico Batista do Sul do Brasil ratificou, segundo sua ata de 29 de novembro de 1994, a decisão de fazer a escritura de promessa de compra e venda com a Empreendimentos e Participações Brunet S/A, em substituição à Construtora Wrobel. Ocorre que posteriormente, num expediente redacional, foi lavrado um termo "em tempo" em que se qualificavam os dois procuradores para assinar os documentos relativos à "escritura de compra e venda". Ora, a autorização do colegiado da Junta, no corpo da Ata de sua reunião, era para a escritura de promessa de compra e venda e não para a escritura de compra e venda. Esse dado foi que lastreou e possibilitou a confecção da alcunhada Escritura de Petrópolis.

Outro fator perturbador é o valor arbitrado para a transação imobiliária. Ora, se a previsão mais pessimista tratava de 13 apartamentos com valores por volta de $\mathrm{R} \$$ 300.000,00 naquele tempo, e se ao dar a Escritura de Petrópolis como garantia para o financiamento do Itáu o valor foi de R \$ 5.474.000,00 (Contrato 1009310/98 que lastreou o instrumento particular com força de escritura pública de 13 de março de 1998), por que o Seminário do Sul não arbitrou um valor maior? Foi para que a construtora pagasse menos imposto? Ora, se havia uma dificuldade de fluxo de caixa pela construtora, não seria aquela a hora e a motivação para desconfiar da saúde financeira dessa empresa?

Um fato novo aconteceu no trato da Junta Administrativa do STBSB no tocante ao acompanhamento da Incorporação. Até o ano de 1997 a Junta teve uma assessoria jurídica externa, pela qual, em diferentes períodos responderam alguns advogados. Só que justamente em 1997, ano em que as supracitadas escrituras foram feitas, destacadamente às $2^{\mathrm{a}}$ e $3^{\mathrm{a}}$, a Junta Administrativa do Seminário do Sul resolveu também contar com uma assessoria jurídica interna, oriunda do seu colegiado. Nesse sentido, dois dos seus componentes são eleitos para assessorar o Reitor. Interessante é que justamente quando a Junta do STBSB demonstrou maior cuidado, adotando um procedimento novo, é que são assinadas a segunda e terceira escrituras. Fato é que as diferentes instâncias de assessoria não conseguiram evitar que flagrantes equívocos fossem cometidos.

Cabe aqui ressaltar outro dado interessante. Um escritório de advocacia passou, a partir de 1999, a assessorar juridicamente o Seminário. Em 01 de abril de 1999 foi

47 AUERBACH, Erich. Mimesis: a representação da realidade na literatura ocidental. São Paulo: Perspectiva, 2011. 
estabelecido um contrato de assessoria jurídica e em 14 de junho de 2000 foi feito outro contrato para administração dos futuros imóveis oriundos da construção dos prédios pela Brunet. Ambos foram denunciados em 23 e 05 de abril de 2001, respectivamente, sendo que em 24 de maio de 2001 foi emitida uma carta cobrança ao Seminário do Sul pelo serviço de assessoria jurídica junto à construtora Brunet, consoante ao relatório prestado pelo Gerente Administrativo, para a Junta do Seminário do Sul. ${ }^{48}$ O que nos parece é que não houve assessoramento tanto para registro da confissão de dívida, quanto para a execução. A explicação para uma assessoria que não assessora vai desde a falta de demanda do contratante até a desídia na execução do contrato, o que torna difícil precisar a razão pela qual a assessoria jurídica não se mostrou eficiente. Somente quando se contratou uma nova assessoria jurídica é que uma ação judicial é proposta. Contudo, essa proposição para deliberação da Junta do Seminário do Sul só foi feita em 05 de novembro de 2001, ocasião esta que o colegiado da Junta do Seminário do Sul toma conhecimento da hipoteca dos apartamentos ao Banco Itaú, feita em 13 de abril de 1998.49 Essa nova e eficiente assessoria ${ }^{50}$ agiu com rapidez, porém ela foi inserida no processo de modo tardio.

A questão que se levanta é: com tantas assessorias jurídicas, da própria Junta do Seminário do Sul, de escritório contratado, da própria Convenção Batista, como foi possível que tanta coisa passasse despercebida? Qual a explicação para isso? Teria o reitor não demandado a Assessoria, ou seria uma questão de debilidade técnica?

Fruto de vários retardos, inclusive da impetração da ação, um posterior Reitor do Seminário do Sul, Israel Belo de Azevedo,51 ao prestar esclarecimentos à Diretoria da CBB, lê a sentença contrária ao STBSB na qual o juiz afirma o "descuido, displicência ou boa fé" do Seminário do Sul ao longo da incorporação e nega a reversão da hipoteca dos apartamentos. ${ }^{52}$ Em Agosto de $2004{ }^{53}$ o reitor comunica a Junta do STBSB que "o embargo declaratório sobre a Construtora Brunet não teve qualquer viabilidade. O Seminário está

48 SEMINÁRIO TEOLÓGICO BATISTA DO SUL DO BRASIL (2001d). Ata da reunião plenária do Conselho Administrativo do Seminário do Sul no dia 05 de novembro de 2001.

49 Um mês antes de lavrar a hipoteca com o Banco Itaú, representantes da Brunet vão à reunião da Junta do Seminário do Sul falar sobre o andamento da obra (SEMINÁRIO DO SUL, 1998b).

50 Trata-se da ASPIM, Escritório de Adilson de Vasconcellos Leal Advogados Associados.

51 Para esclarecimento, nas muitas voltas que o mundo dá (principalmente o batista), o Prof. Israel Belo de Azevedo demitido em 1987 pelo STBSB veio a ser seu Reitor posteriormente.

52 CONVENÇÃO BATISTA BRASILEIRA (2003). Ata de número 60 do Conselho de Planejamento e Coordenação da Convenção Batista Brasileira realizada em 19 de março de 2003.

53 Nesse mesmo dia a Junta do STBSB votou em sua reunião deliberativa pedir à CBB autorização para vender o apartamento da Rua José Higino 54, Bloco 1, Ap. 201 para cobrir seus gastos. No dia seguinte em documento assinado por dois membros da assessoria jurídica da CBB, é dado parecer favorável com duas cláusulas: que o STBSB faça constar os dados completos do imóvel para registro em Ata; e o STBSB informe sobre a destinação dos recursos recebidos pela venda (CONVENÇÃO BATISTA BRASILEIRA (2004b). Ata da reunião do Conselho de Planejamento e Coordenação da Convenção Batista Brasileira realizada em 19 de agosto de 2004). 
desistindo da ação, para impetrar outra, que requererá recursos financeiros ainda não disponíveis". 54

O mais incrível nesse período pós-assinaturas de escrituras, herdadas da era Ferreira, é a passividade administrativa representada pelos reitores que o sucederam. $\mathrm{O}$ primeiro reitor que assumiu seu lugar, um reconhecido líder, exala sua expectativa de que o empreendimento acabe e seja entregue as unidades ainda no primeiro semestre de 2000.55 No mesmo período do ano seguinte, este conceituado Reitor informa à mesma instância que o prazo para entrega dos apartamentos fora encerrado em Dezembro de 2000 e que a Brunet havia pedido novo prazo sendo atendida até Fevereiro de 2001, sem sucesso. ${ }^{56}$

Já em outro momento e sob o comando do Pr. Israel Belo de Azevedo, no meio de toda crise institucional e financeira, é manifesto à Junta do Seminário do Sul a possibilidade dele se tornar uma Universidade. ${ }^{57}$ Esta palavra foi dada num contexto em que um dos membros da Junta com sólida carreira como advogada, admitia a possibilidade da perda da ação contra a Brunet em $1^{\mathrm{a}}$ Instância e defendia a entrada em $2^{\mathrm{a}}$ Instância. ${ }^{58}$ Percebe-se que não é só um caso de inépcia administrativa, mas sobretudo, de desconexão da realidade, seja por acreditar que uma empresa iria agora se tornar adimplente, seja no devaneio expresso da criação de uma Universidade num momento de franca deterioração acadêmica, institucional, financeira e patrimonial.

A quem interessava e por que dessa morosidade decisória? Parte da explicação está naquilo que vimos chamando de má gestão da res Batista. A má gestão que incide em erros crassos e em procrastinações tem feito uma denominação histórica como os batistas passarem mais tempo debruçados sobre problemas do que sobre estratégias e ampliação da visão do trabalho. Essa in-digestão da coisa batista é que avolumou a segunda onda.

Um destaque deve ser dado ao Pr. David Malta do Nascimento. Ele exerceu a função de assessor voluntário da ADEBRJ por muitos anos. Ele mesmo não entendia como uma procuração para se lavrar uma escritura de promessa de compra e venda pôde se tornar uma escritura de compra e venda num dado momento. Mesmo sendo alvo de posterior e injusta suspeição, foi ele o grande responsável pelo alarde que fez com que a Junta do Seminário do Sul tomasse as primeiras medidas cabíveis.

\footnotetext{
SEMINÁRIO DO SUL, 2004b.

CONVENÇÃO BATISTA BRASILEIRA (2000). Relatório/março/2000.

CONVENÇÃO BATISTA BRASILEIRA (2001). Relatório/março/2001.

AZEVEDO, Israel Belo de (2003), Relatório/março/2003.

58 SEMINÁRIO TEOLÓGICO BATISTA DO SUL DO BRASIL (2003). Ata da reunião plenária do Conselho Administrativo do Seminário do Sul no dia 17 de março de 2003.
} 
Diante da decisão da Junta de vender dois apartamentos para reforçar o seu caixa, ${ }^{59}$ Pr. David ajudou a achar um comprador, cuja amizade era de longa data. Foi então vendido um apartamento que gerou um contrato a parte entre o Seminário do Sul e a Brunet. Entretanto o comprador comentara com Pr. David a dificuldade que estava tendo para registrá-lo. Dessa feita, ainda em 16 de outubro de 2001 Pr. David soa o alarido de alerta que fez com que o Conselho do Seminário do Sul pedisse uma certidão de ônus reais do imóvel da Rua Homem de Melo chegando ao conhecimento da hipoteca em favor do Banco Itaú. Por serem as medidas tomadas extemporaneamente não houve efeito algum.

\section{As Consequências da Perda}

O caso da perda dos apartamentos pelo Seminário do Sul não só ilustra a dificuldade administrativa pela qual passou a Junta Administrativa do Seminário Teológico Batista do Sul do Brasil, como também aponta para o trato de questões intestinas no âmbito das denominações protestantes históricas. Mais particularmente no caso do STBSB há consequências mensuráveis e outras que ao longo do tempo serão compreendidas pelo seu desdobramento histórico.

A perda não foi ocasionada por uma única gestão; no entanto é inegável que as bases para que ela acontecesse estivessem na era pós David Malta. Houve protelação no ajuizamento da causa, falta de observância dos contratos e escrituras, dificuldades com assessoria jurídica, entre outros. Tais pontuações incidem, no nosso entendimento, também sobre as três gestões que sucederam Ferreira, lembrando, entretanto, que elas não lançaram as bases da perda.

O apontamento sobre as bases é importante para contrastar com um dos fatos mais intrigantes desse processo todo: a rescisão contratual do então Reitor em 1999. A partir de um parecer da comissão de finanças da Junta do STBSB ficou estabelecido:

1. Que o Seminário torne-se um referencial para as demais entidades denominacionais, quanto ao trato das questões relacionadas com a aposentadoria digna dos homens de Deus que têm dedicado suas vidas à causa do Senhor no âmbito denominacional, como é o caso do Pr. Ebenézer Soares Ferreira, que desde 1984 serve a esta Instituição na qualidade de Reitor, desenvolvendo um ministério digno de toda a honra e reconhecimento.

2. Que na ocasião do encerramento de suas atividades como executivo desta Instituição, o Pr. Ebenézer Soares Ferreira, tenha preservados todos os seus direitos trabalhistas estabelecidos pela lei vigente os $40 \%$ do FGTM.

3. Que por ocasião do referido processo, esta Junta estabeleça, mediante Parecer desta Comissão, um plano de benefício vitalício.

59 SEMINÁRIO TEOLÓGICO BATISTA DO SUL DO BRASIL (2001c). Ata da reunião plenária do Conselho Administrativo do Seminário do Sul no dia 02 de agosto de 2001. 
4. Que esta Junta passe a custear, a partir deste mês, um plano de saúde para o Reitor e que o mesmo também tenha caráter vitalício [sic]. ${ }^{60}$

Além dessas resoluções, posteriormente (em 06 de março de 2001) a Junta do Seminário do Sul lhe outorgou o título de Doutor em Divindades. ${ }^{61}$ Não está se querendo julgar aqui a questão humanitária e cordial de tais resoluções, nem tampouco a intenção dos proponentes de tal decisão. A questão é o contraste entre uma administração complicada que legou uma série de problemas para o Seminário do Sul e sua forma de recompensa. O responsável por uma gestão complicada passa incólume aos dissabores que legou para a própria Instituição. Mesmo após ter assumido uma paternidade indevida (ideia da permuta do terreno por apartamentos), e ter sido signatário de documentos, escrituras no mínimo questionáveis, sua imagem como bom gestor não foi arranhada.

Outra consequência foi a predominância do assunto em quase todas as reuniões administrativas da Junta do Seminário do Sul, e depois tomando parte da pauta do CPC da CBB e das próprias Assembleias Convencionais. As atas das reuniões da Junta do STBSB dão conta de que em 29 de novembro de 1994 quando a Construtora Wrobel passa o seu direito à incorporação à construtora Brunet, ${ }^{62}$ diversas vezes os sócios da Brunet estiveram nas reuniões daquela Junta Administrativa. As atas testemunham da presença e esclarecimentos nas reuniões de 06 de março de 1996, 06 de agosto de 1996,63 04 de novembro de 1997,64 e nos dias 16-17 de março de 1998 dando retorno sobre o andamento da obra. Há ainda um pedido formal da Construtora Brunet feito em Dezembro de 2001 para que fosse dado mais tempo para a liberação das hipotecas. ${ }^{65}$ A questão é que num tempo que pedia o estudo e a rápida entrada com o processo de reconhecimento do curso junto ao Ministério da Educação, a administração do Seminário, que já não dava conta de sua atividade fim, agora se via envolta com questões atinentes à Incorporação de Imóveis. Este preterimento do processo de reconhecimento custou caro ao Seminário do Sul,

60 SEMINÁRIO TEOLÓGICO BATISTA DO SUL DO BRASIL (1998a). Ata da reunião plenária da Junta Administrativa do Seminário do Sul no dia 16 de março de 1998. Anexo II.

61 SEMINÁRIO TEOLÓGICO BATISTA DO SUL DO BRASIL (2001a). Ata da reunião plenária do Conselho Administrativo do Seminário do Sul no dia 05 de março de 2001.

${ }^{2} \mathrm{Na}$ Ata da Junta do STBSB de 29 de novembro de 1994 consta o termo de passagem da "escritura de compra e venda" para a Brunet em substituição a Wrobel. A escritura do Seminário do Sul com a Wrobel foi de "promessa de compra e venda" feita na grande Vitória-ES, da onde vinha a procuração do Presidente da Associação Denominada Evangélica Batista do Rio de Janeiro. Ao que tudo indica foi usada a procuração do então presidente da Associação Evangélica Denominada Batista do Rio de Janeiro. Tal procuração é datada de 18 de novembro de 1991, do $3^{\circ}$ Ofício de Notas de Vila Velha - ES, Livro 127, Folha 057. Em 10 de dezembro de 1991 foi assinada a escritura de promessa de compra e venda entre o Seminário do Sul e a Construtora Wrobel, sendo os signatários pelo STBSB o Reitor juntamente de um membro da Junta Administrativa do Seminário do Sul (SEMINÁRIO TEOLÓGICO BATISTA DO SUL DO BRASIL (1994). Ata da reunião plenária da Junta Administrativa do Seminário do Sul no dia 29 de novembro de 1994. p. 53).

63 A construtora estima o processo documental para a Incorporação.

64 Os sócios da Construtora Brunet falam sobre o adiamento da obra, dando as suas razões para tal fato.

65 SEMINÁRIO TEOLÓGICO BATISTA DO SUL DO BRASIL (2001b). Ata da reunião plenária do Conselho Administrativo do Seminário do Sul no dia 12 de abril de 2001. 
especialmente à sua posição de vanguarda teológica no meio batista. Perdeu seu prestígio e seu espaço de referência para os demais seminários batistas reunidos na Associação Brasileira de Instituições Batistas de Ensino Teológico (ABIBET).

Houve uma perda de crédito também pela via administrativa. O STBSB como instituição passou a ser desacreditado. Um exemplo disso pode ser a decrescente matrícula. Se em Março de 1984 o Seminário do Sul dava conta de uma matrícula de 135 novos alunos somente na sua sede, 66 em 2001 é informado à Junta do Seminário a aprovação de 102 candidatos no exame de ingresso, o que não implicou necessariamente em matrícula. ${ }^{67}$ Já em março de 2004 a Junta do Seminário toma conhecimento que o total de matriculados, em todos os cursos, não passava dos 495 alunos. ${ }^{68}$ Ora, para uma instituição que contava nos anos 80 e 90 com mais de 1000 alunos matriculados em seus diferentes cursos, passar a ter no século XXI menos da metade é um claro sinal de fraqueza institucional. O decréscimo acentuado de alunos imputou ao Seminário uma espiral descendente para sua gestão financeira. $\mathrm{O}$ que era ruim ficou ainda pior.

Para um foco de Ciência da Religião esse dado é interessante porque ele remete ao preparo dos líderes religiosos batistas, àqueles que conduzirão pessoas dentro da doutrina e rito batista. Ocorre que a qualidade desse preparo se torna comprometida, especialmente com a proliferação de seminários patrocinados por igrejas locais, ocorrida no vácuo deixado pelo Seminário do Sul. Se antes líderes saíam com uma disposição de diálogo com a cultura, agora saem com um olhar visceral. Isso afeta o diálogo inter-religioso, os esforços ecumênicos, a agenda para discutir problemas sociais, o engajamento nos processos de transformação da estrutura social, entre outros. A excentricidade, uma das marcas da experiência religiosa brasileira, ganha novos contornos e possibilidades com essa proliferação de seminários menores.

Em termos do Seminário do Sul, diante das dificuldades financeiras quase que intransponíveis que passou a experimentar, houve uma proposta de sua própria Junta para que devolvesse a gigantesca propriedade onde está inserido para a CBB a fim de que ela passasse a gerir e cuidar do imenso espaço físico cuja manutenção passou a ser cara diante do decréscimo de alunos. ${ }^{69}$ Com isso o Pr. Hélio Schwartz Lima, ${ }^{70}$ consoante ao arrazoado de sua proposição, esperava que o Seminário do Sul pudesse aplicar melhor seus recursos na atividade fim. O problema é que essa devolução não só representou uma

66 CONVENÇÃO BATISTA BRASILEIRA, 1984.

67 SEMINÁRIO DO SUL, 2001a.

68 SEMINÁRIO TEOLÓGICO BATISTA DO SUL DO BRASIL (2004a). Relatório/abril/2004. p. 11.

69 SEMINÁRIO TEOLÓGICO BATISTA DO SUL DO BRASIL (2006). Ata da reunião plenária do Conselho Administrativo do Seminário do Sul no dia 08 de agosto de 2006

70 Uma pequena digressão e observação. Há um inquietante registro do pedido do Seminário do Sul para uso da propriedade em regime de comodato sem maiores dados documentais, o qual foi remetido à Associação Evangélica Denominada Batista do Rio de Janeiro (ATA NÚMERO 60 do CONSELHO DE PLANEJAMENTO E COORDENAÇÃO DA CONVENÇÃO BATISTA BRASILEIRA, de 19 de março de 2003). 
contínua perda patrimonial com uma nova venda de área do Seminário do Sul sendo feita (área dos prédios 25 e 26, que dão saída para a Rua Homem de Melo), como também na impossibilidade de expansão do Seminário através do oferecimento de seu internato. Soma-se a esses fatores o asfixiamento da teologia batista, uma vez que o Seminário passou a respirar o pesado ar institucional, conquanto ainda funcione no alto de uma arborizada colina tijucana. Como bem lembra Urbano Zilles, a teologia deve ser feita com liberdade, para que se possa falar em responsabilidade. ${ }^{71}$ Por isso que "ao tentar reduzir o discurso teológico a um discurso intra-eclesial, não se deve estranhar que este cada vez menos convencerá os próprios fiéis, e o diálogo com interlocutores externos se torna fictício" ${ }^{72}$ Os ares institucionais quando assumem a cátedra teológica, acabam tornando-a rarefeita. Esquecem-se os líderes que os teólogos "falam de dentro da Igreja, não por ela". ${ }^{73}$

Essa ocupação do espaço destinado ao internato é o que chamamos de terceira onda. O STBSB com seu vasto internato ${ }^{74}$ preservava sua abrangência nacional. Ao perder tais espaços (prédios Djalma Cunha, conhecido como 19, e Ricardo Inke, conhecido como 18) ele se resignou a ser um seminário local, regional.

Nessa enumeração de fatores resta apontar mais três. $O$ primeiro reside no imbróglio que a perda dos apartamentos gerou, fazendo com que a Junta do STBSB de gestão posterior pedisse a interveniência da Diretoria da Convenção para investigar e esclarecer "atos praticados por outros dirigentes" ${ }^{75} \mathrm{Na}$ época o Presidente e Reitor do STBSB se resguardaram do desgaste que o conhecimento público denominacional traria ao expor esse assunto. Interessante que a preocupação com a imagem, e não mais com a solução do problema, passou a ser a tônica. Na Ata da Reunião Extraordinária do Conselho de Planejamento e Coordenação da Convenção Batista Brasileira (22 de janeiro de 2005, p. 4), está registrado a preocupação dos conselheiros com o "pronunciamento do presidente". Era explicar o inexplicável. Pronunciamento este que vinha da divisão do ônus da imagem feita pela direção do Seminário do Sul e também da ciência do Conselho da Convenção da recomendação feita em Assembleia de janeiro de 2004 para que promovesse um encontro com todos os líderes denominacionais envolvidos em todo o processo de negociação e execução da Incorporação, desde reitores a membros da Junta Administrativa do Seminário. ${ }^{76}$ Tal proposta deveria ser observada para embasar o pronunciamento do Presidente da Convenção, devidamente assessorado juridicamente

71 ZILLES, Urbano. A teologia é ciência? Revista Eclesiástica Brasileira, Petrópolis, ano 74, n. 294, p. 300-319, abr./jun. 2014. à p. 304.

72 ZILLES, 2014, p. 304.

73 ZILLES, 2014, p. 304.

74 Entre alunos, familiares e funcionários estima-se uma comunidade de cerca de 2000 pessoas convivendo diariamente no campus do Seminário, nas décadas de oitenta e noventa.

75 CONVENÇÃO BATISTA BRASILEIRA, 2003.

76 CONVENÇÃO BATISTA BRASILEIRA (2004a). Relatório/abril/2004. p. 11. 
para evitar maiores danos à imagem da obra denominacional. Conquanto houvesse esta precaução, o estrago estava feito. O cuidado foi extemporâneo.

Por fim destaca-se o legado desse processo aos alunos dos seminários. A Ata da $11^{a}$ Sessão da $85^{\mathrm{a}}$ Assembleia da Convenção Batista Brasileira realizada no Riocentro, Rio de Janeiro, em 25 de janeiro de 2005 traz às seguintes recomendações do plenário para a CBB como um todo:

1. Todos os contratos a serem firamos pelos seminários, de qualquer natureza de ordem patrimonial, sejam consultados e avaliados pela CBB, antes de formalizados.

2. Que os seminários façam constar da matriz curricular, na Disciplina Administração Eclesiástica, o item 'Noções de Direito', visando instrumentalizar os futuros obreiros em conhecimento jurídico (...). ${ }^{77}$

Ocorre que o proponente, possivelmente por desconhecimento de causa, penalizou os seminaristas na segunda parte de sua proposta como se eles tivessem alguma responsabilidade sobre o assunto. Na verdade o Reitor que assinou as escrituras com a Construtora Brunet é bacharel em direito. Além disso, a Junta do Seminário do Sul nessa mesma ocasião possuía outros advogados em sua composição, assim como havia uma empresa contratada para prestar assessoria jurídica ao Seminário. Ao que tudo indica, não foi por desconhecimento jurídico que tais perdas aconteceram.

\section{Conclusão}

Ao se evidenciar todo o processo da perda dos apartamentos e do terreno, bem como os desdobramentos que isso teve em termos de desgaste, de debate e de ocupação de pautas decisórias, procuramos trazer a lume o relacionamento existente entre Religião e Economia e seu impacto na estruturação social de um grupo religioso.

A boa gestão dos recursos patrimoniais e financeiros possibilitou que o Seminário do Sul alcançasse seu auge no início da década de 1980 sob a gestão do Pr. David Malta do Nascimento. Esses recursos foram essenciais para a formação e manutenção de um singular corpo docente que melhor representou a alma do Seminário do Sul, numa mescla entre o saber e a devoção, os quais estão aproximados e simbolizados na figura de sua própria disposição patrimonial, na qual Biblioteca e Capela foram construídas lado a lado, e ligados por um pequeno foyer. Inclusive as portas dão uma para a outra, evidenciando essa aproximação e o trânsito que deve haver entre devoção e saber para uma casa que visa o preparo teológico-ministerial de seus alunos.

77 CONVENÇÃO BATISTA BRASILEIRA (2005). Ata da reunião extraordinária do Conselho de Planejamento e Coordenação da Convenção Batista Brasileira realizada em 22 de janeiro 2005. p. 4. 
Contudo, com a chegada do novo reitor, o qual foi elegantemente saudado pelo Pr. David Malta Nascimento em relatório datado de 11 de dezembro de 1984,78 esse período de crescimento acadêmico, financeiro e, sobretudo institucional se esvaiu.

Dentro do espectro da Teologia e da Ciência da Religião há pelo menos dois fatores que são atingidos com esse episódio. O primeiro está no preparo de futuros líderes, principalmente batistas, que ajudarão suas comunidades a elaborarem seu pensamento religioso, a cumprirem os ritos e a interpretarem a vida. Nesse sentido quanto pior o preparo, e quanto mais fraca a Instituição, tanto mais fácil é que se tenham crescentes embates religiosos e não diálogos, o aumento das excentricidades feitas em nome de Deus, a promoção de neuroses e doenças psíquicas a partir da religião e, sem querer esgotar a lista, porém terminando-a, o uso desenfreado dos dois principais mecanismos de manipulação religiosa, a saber: culpa e medo. No campo da Instituição ela se torna suscetível às sedutoras abordagens fundamentalistas, sendo alvo fácil de cooptação do seu ideário pelo viés financeiro, o que normalmente impinge constantes mudanças no corpo docente. Tal experiência se repete ao longo do tempo em diferentes seminários teológicos.

Outro aspecto é o elemento combustível, alimentador do fenômeno cultural do pós-denominacionalismo. Num tempo de crescente repúdio e repulsa às formas mais institucionalizadas de expressão religiosa, o conhecimento de um grave erro administrativo como esse da perda dos apartamentos, alimenta ainda mais o distanciamento das pessoas a toda e qualquer forma de organização religiosa. Se o pósdenominacionalismo como fator cultural era algo que vinha de fora, agora com as decepções administrativas ele encontra uma liga, uma coesão interna na estrutura denominacional que atinge diretamente a visão do fiel. Incrivelmente ocorre um fenômeno no meio batista ligado a essa visão da denominação. Em suma, a visão dos batistas sobre a sua denominação não é boa, enquanto que a visão das pessoas de fora sobre os batistas costuma ser a melhor possível.

A pesquisa teológica e porque não dizer, em termos de Ciência da Religião, também sofreu um severo decréscimo. No final dos anos 70 e início dos anos 80 o Seminário do Sul produzia a mais fina pesquisa teológica (e de temas ligados também à Ciência da Religião) entre os batistas da América Latina. Em suas monografias de bacharelado arquivadas na Biblioteca da Instituição, há diferentes tipos de pesquisas, muitas delas apontando para um certo pioneirismo temático. Tal produção se viu comprometida com a perda do corpo docente promovida na gestão de Ferreira, além do novo flerte fundamentalista que o Seminário do Sul sofreu e ainda sofre.

Outro fator de embaraço à pesquisa é a consecução da cidadela batista na segunda década do século XXI. Ora, o saber teológico precisa de certa abertura, de oxigênio para que ele seja fluído. Com a presença institucional dentro da ambiência acadêmica do

78 NASCIMENTO, 1985, p. 274. 
Seminário do Sul, a densidade do ar fatalmente afetará a produção acadêmica da Instituição. Essa centralização administrativa despersonalizou a estrutura batista, desatrelando-a de sua marcada liberdade e autonomia. Essa perda de identidade contribuiu para a expansão de um viés conservador ditado, e não mais construído, por lideranças que, ao menos flertam com o fundamentalismo estadunidense.

A onda fundamentalista não queria só o enfraquecimento daquele Seminário do Sul, mas especialmente sua cooptação. Ao perder qualidade e recursos, o STBSB se tornou dependente de financiamento externo, impelindo-o ao encontro das grandes fontes de financiamento que há muito estão nas mãos do fundamentalismo estadunidense. Prova disso é a recente assinatura do convênio entre o Seminário Batista do Sul e o Southwestern Baptist Theological Seminary, Fort Worth, Texas, cujo até então reitor se identifica como sendo um dos principais protagonistas do golpe fundamentalista que a Convenção Batista do Sul dos Estados Unidos sofreu no final da década de 70 e início da década de 80 do século passado. Ressalta-se, porém, que antes mesmo da assinatura desse acordo, essa ideologia já tinha adentrado pelos portões e salas de aula do Seminário do Sul.

Por fim, a perda de prestígio do Seminário do Sul fomentou a proliferação de outros seminários até mesmo entre os batistas. E como não é possível manter a qualidade acadêmica onde há proliferação de cursos, de seminários, a qualidade do preparo ministerial sofreu sensível perda. O caso e ocaso do Seminário do Sul apontam não só para a vitória de uma onda fundamentalista, como também para o próprio acanhamento dos Batistas.

A perda da qualidade e do encanto com a administração batista, e a agenda voltada para o trato do que anteriormente chamamos de passivo e passado, fez com que os Batistas da CBB mergulhassem em embates e debates sem fim retirando deles a possibilidade de ter uma agenda propositiva e de maior diálogo cultural. Sem buscar entender o contexto cultural presente e seus desafios, com um preparo deficiente de líderes, e voltado para assuntos intestinos, os batistas não puderam pensar nem planejar seu crescimento. O que ocorreu, quando ocorreu, é tomado como por divino acidente. E essa ausência de vistoso crescimento legou aos batistas, ao nosso ver, um esquecimento das pesquisas no campo da Teologia, das Ciências Sociais e da Ciência da Religião.

\section{Referências}

AUERBACH, Erich. Mimesis: a representação da realidade na literatura ocidental. São Paulo: Perspectiva, 2011.

AZEVEDO, Israel Belo de (2003). Relatório/março/2003.

CAMPOS, Leonildo Silveira. Teatro, templo e mercado: organização e marketing de um empreendimento neopentecostal. Petrópolis: Vozes; São Paulo: Simpósio Editora/UMESP, 1997. 
CASTRO, Alexandre de Carvalho; DUSILEK, Sérgio Ricardo Gonçalves; SILVA, Clemir Fernandes. Identidade Social, Mídia Televisiva e Construção Histórico-Cultural da Memória Coletiva: o caso de um movimento sócio-religioso no Brasil. Religião e Sociedade, Rio de Janeiro, v. 36, n. 1, p. 74-102, 2016

CENSO DEMOGRÁFICO 2010. Características gerais da população, religião e pessoas com deficiência. Rio de Janeiro: IBGE, 2012. Disponível em:

<https:// biblioteca.ibge.gov.br/visualizacao/periodicos>. Acesso em: 16 nov. 2017.

CONVENÇÃO BATISTA BRASILEIRA (1984). Ata da 65ª Assembleia da Convenção Batista Brasileira. In: CBB. Livro do Mensageiro. Rio de Janeiro: CBB, 1985.

. (1978). Anais da 59a Assembleia da CBB, 1978. In: CBB. Livro do Mensageiro. Rio de Janeiro: CBB, 1979.

- (1983). Ata da reunião plenária da Junta Executiva da Convenção Batista Brasileira realizada em 13 de dezembro de 1983.

- (1984). Ata da reunião plenária da Junta Executiva da Convenção Batista Brasileira realizada em 28 de fevereiro de 1984.

. (1988). Anais da 70a Assembleia da convenção batista brasileira, 1988. In: CBB. Livro do Mensageiro. Rio de Janeiro: CBB, 1989.

. (1999). Relatório/março/1999.

. (2000). Relatório/março/2000.

. (2001). Relatório/março/2001.

. (2003). Ata de número 60 do Conselho de Planejamento e Coordenação da Convenção Batista Brasileira realizada em 19 de março de 2003.

- (2003). Ata da reunião da diretoria da Convenção Batista Brasileira realizada em 29 de novembro de 2003.

. (2004a). Relatório/abril/2004.

- (2004b). Ata da reunião do Conselho de Planejamento e Coordenação da Convenção

Batista Brasileira realizada em 19 de agosto 2004.

- (2005). Ata da reunião extraordinária do Conselho de Planejamento e Coordenação da Convenção Batista Brasileira realizada em 22 de janeiro 2005.

- (2005). Ata da $11^{a}$ Sessão da 85a Assembleia da Convenção Batista Brasileira, 2005. Rio de Janeiro: 25 jan. 2005.

DUSILEK, Darci. Oásis no deserto. Missão: Revista Evangélica de Cultura, Rio de Janeiro, v. 1, n. 1, p. 27-38, Verão de 1985. 
DUSILEK, Sérgio Ricardo Gonçalves; SILVA, Clemir Fernandes; CASTRO, Alexandre de Carvalho. A Igreja de Farda: Batistas e a Ditadura Civil-Militar. Estudos Teológicos, v. 57, n. 1, p. 192-212, jan./jun. 2017.

DUSILEK, Sérgio Ricardo Gonçalves. O Encontro da História com a Religião na Narratividade de Paul Ricoeur. Conferência apresentada no $1^{\circ}$ Simpósio Conhecer e Fazer História promovido pela UNISUAM, Rio de Janeiro, 31 de agosto de 2017.

FERREIRA, Ebenézer Soares; HALLOCK, Edgar Francis. História do Seminário Teológico Batista do Sul do Brasil, 1908 a 1998. Rio de Janeiro: Dos Autores, 1998.

FERREIRA, Ebenézer Soares. Entrevistas concedidas por email a Sérgio Ricardo Gonçalves Dusilek em: 13 jun. 2016 (a) e 17 jun. 2016 (b).

. (1998). Relatório/novembro/1998.

. (1999). Relatório/março/1999.

NASCIMENTO, David Malta do. Relatório da Junta do Seminário Teológico Batista do Sul do Brasil. In: ASSEMBLEIA DA CONVENÇÃO BATISTA BRASILEIRA, 1985, Maceió. Anais da 66 Assembleia da Convenção Batista Brasileira. Rio de Janeiro: CBB, 1986.

SEMINÁRIO TEOLÓGICO BATISTA DO SUL DO BRASIL (1987). Ata da reunião plenária da Junta Administrativa do Seminário do Sul no dia 20 de janeiro de 1987.

. (1991). Ata da reunião plenária da Junta Administrativa do Seminário do Sul no dia 12 de março de 1991.

(1994). Ata da reunião plenária da Junta Administrativa do Seminário do Sul no dia 29 de novembro de 1994.

. (1996). Ata da reunião plenária da Junta Administrativa do Seminário do Sul no dia 27 de novembro de 1996.

- (1998a). Ata da reunião plenária da Junta Administrativa do Seminário do Sul no dia 16 de março de 1998. Anexo II.

de março de 1998.

(1998b). Ata da reunião plenária da Junta Administrativa do Seminário do Sul no dia 17

- (2001a). Ata da reunião plenária do Conselho Administrativo do Seminário do Sul no dia 05 de março de 2001.

- (2001b). Ata da reunião plenária do Conselho Administrativo do Seminário do Sul no dia 12 de abril de 2001.

. (2001c). Ata da reunião plenária do Conselho Administrativo do Seminário do Sul no dia 02 de agosto de 2001.

- (2001d). Ata da reunião plenária do Conselho Administrativo do Seminário do Sul no dia 05 de novembro de 2001. 
- (2003). Ata da reunião plenária do Conselho Administrativo do Seminário do Sul no dia 17 de março de 2003.

. (2004a). Ata da reunião plenária do Conselho Administrativo do Seminário do Sul no dia 29 de março de 2004.

- (2004b). Ata da reunião plenária do Conselho Administrativo do Seminário do Sul no dia 18 de agosto de 2004.

. (2006). Ata da reunião plenária do Conselho Administrativo do Seminário do Sul no dia 08 de agosto de 2006.

VOLTAIRE. Cartas Inglesas ou Cartas Filosóficas. São Paulo: Abril, 1973. p. 7-63 (Coleção Os Pensadores, 1.ed.)

WEBER, Max. A ética protestante e o espírito do capitalismo. São Paulo: Martin Claret, 2002.

WHITE, Hayden. The Metaphysics of Narrativity: Time and symbol in Ricoeur's philosophy of history. In: WOOD, David (Ed.). On Paul Ricoeur: narrative and interpretation. London and New York: Routledge, 1991. p. 140-159.

ZAMBROTTI, Renato Cerqueira. Entrevista concedida por email a Sérgio Ricardo Gonçalves Dusilek em 23 maio 2016.

ZILLES, Urbano. A teologia é ciência? Revista Eclesiástica Brasileira. Petrópolis, ano 74, n. 294, p. 300-319, abr./jun. 2014. 